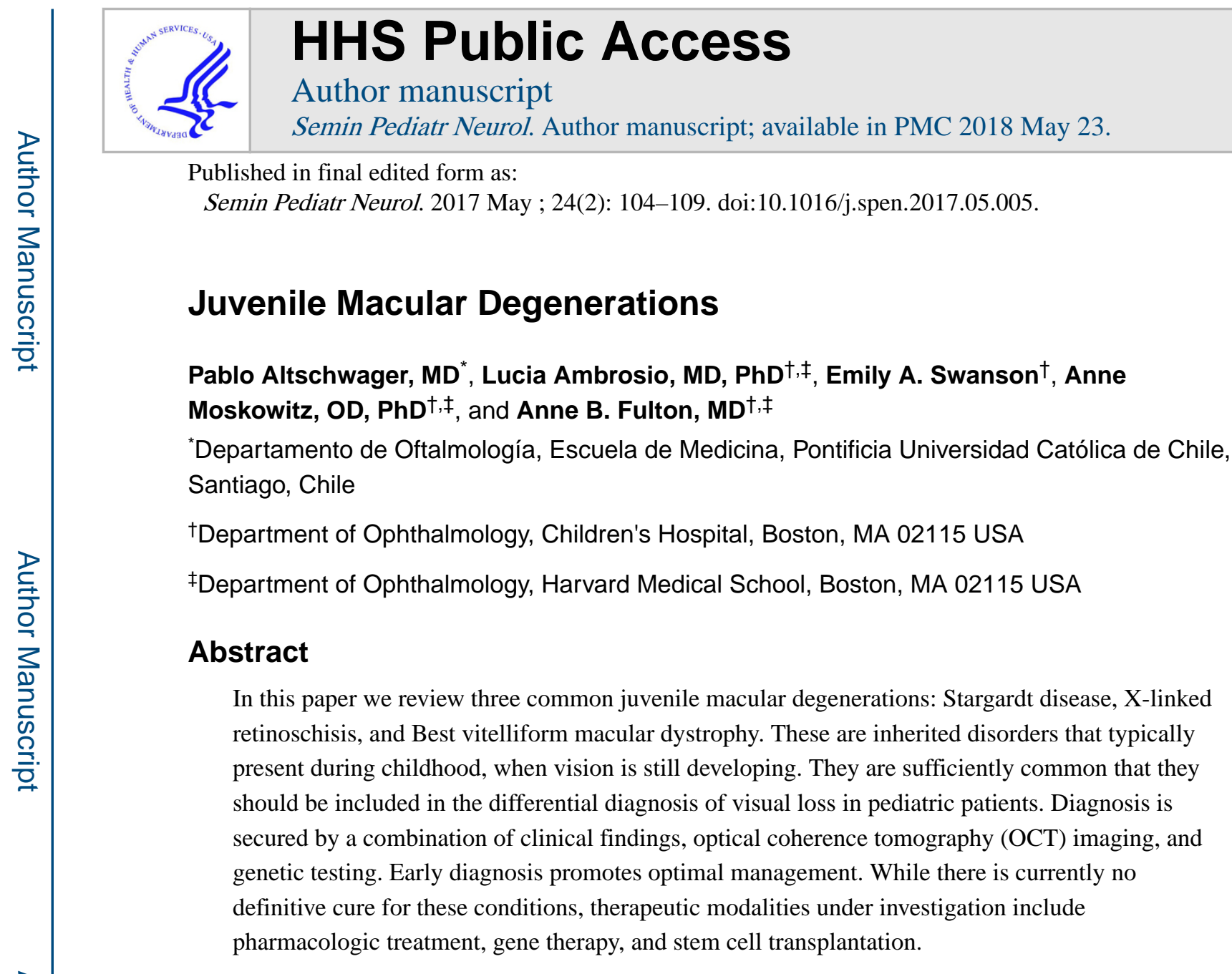

\title{
Introduction
}

Patients with a juvenile macular degeneration (JMD) may present initially to a neurologist or neuro-ophthalmologist with poor vision or nystagmus. Age at presentation is typically early childhood, but older or younger is possible. On the other hand, a child with JMD may be asymptomatic and the eye or vision problem may be identified on a pediatrician's or school screening exam. Family history may lead to identification and diagnosis, as each of the JMDs is a heritable condition.

The macula is a region of the central retina that represents approximately $5 \%$ of the total retinal area. Within the macula is a specialized region, the fovea, in which cone photoreceptors are packed tightly in an approximately $4^{\circ}$ to $5^{\circ}(1.5 \mathrm{~mm})$ rod-free zone. The fovea is highly specialized, and mediates fine visual acuity.

Development of the fovea starts preterm and continues post-term into adolescence. ${ }^{1 ; 2 ; 3}$ The macula, including the fovea, is the last retinal region to reach maturity. $2 ; 4 ; 5 ; 6$ The

Address reprint requests to Pablo Altschwager, MD, Departamento de Oftalmología, Escuela de Medicina Pontificia, Universidad Católica de Chile, Santiago, Chile. paltschwager@med.puc.cl.

Publisher's Disclaimer: This is a PDF file of an unedited manuscript that has been accepted for publication. As a service to our customers we are providing this early version of the manuscript. The manuscript will undergo copyediting, typesetting, and review of the resulting proof before it is published in its final citable form. Please note that during the production process errors may be discovered which could affect the content, and all legal disclaimers that apply to the journal pertain. 
specialized neurovascular structure makes this central retinal region vulnerable to disease. The types of disease that may affect the pediatric retina include the JMDs, developmental anomalies, and retinal disease in the setting of metabolic disorders. Among the more frequently seen developmental anomalies is foveal hypoplasia, as in albinism ${ }^{7}$ and $P A X 6$ gene mutation. ${ }^{8}$ Among the more frequently seen metabolic disorders is cobalamin $\mathrm{C}$ type methylmalonic aciduria and homocystinuria. ${ }^{9}$

There are some other uncommon macular degenerations including some forms of Leber congenital amaurosis ${ }^{10 ; 11 ; 12}$, North Carolina macular dystrophy ${ }^{13}$, Sjögren Larsson syndrome $^{14}$, Alagille syndrome ${ }^{15}$, and juvenile neuronal ceroid lipofuscinosis. ${ }^{16}$

The common juvenile macular degenerations are Stargardt disease, X-linked retinoschisis, and vitelliform macular dystrophy. ${ }^{17 ;} 18$

Although each of these is much less common than strabismus or amblyopia, pediatric macular disorders affect a substantial number of children in the pre-school and school years and must be included in the differential diagnosis of visual loss in pediatric patients. The awareness of these conditions promotes an early diagnosis and optimal management.

\section{Stargardt Disease}

Stargardt disease (STGD) is the most common juvenile macular degeneration, with a prevalence of 1 in $10,000 .{ }^{19} \mathrm{~A}$ frequent cause is biallelic mutations in the $A B C A 4$ gene, which encodes for a rim protein located in the outer segment of the photoreceptors, both rods and cones; the protein is a transporter of vitamin A derivatives. ${ }^{20}$ The malfunction of this transporter leads to accumulation of all-trans retinal, which results in increased concentration of a toxic byproduct, $\mathrm{N}$-retinylidene-N-retinyl-ethanolamine (A2E), which is a major component of lipofuscin. Lipofuscin accumulates in the retinal pigment epithelium (RPE), causing RPE cell dysfunction, and consequent photoreceptor death. ${ }^{21 ; 22}$

$A B C A 4$ disease is inherited in an autosomal recessive manner. $A B C A 4$ is a large gene. ${ }^{23} \mathrm{It}$ is highly heterogeneous and many disease-causing variants have been described. ${ }^{24}$ The clinical presentation is also heterogeneous, with a spectrum of conditions: maculopathy, generalized cone-rod dystrophy, and increased susceptibility to age related macular dystrophy. Other less frequent genetic causes of STGD are PROM125 and ELOVL4. ${ }^{26}$ $P R O M 1$ is autosomal recessive and ELOVL4 is autosomal dominant.

Regardless of the genetic cause, STGD usually presents as bilateral symmetric decrease in visual acuity during the first or second decade. Generally speaking, early-onset progresses to lower final acuity $(20 / 200)^{27 ; 28}$; later onset has a better prognosis, and foveal structure and function may be preserved. $29 ; 30 ; 31$

STGD is notorious for presenting with poor vision before any ophthalmoscopic changes are visible. The child may mistakenly be labelled a malingerer. Early signs by ophthalmoscopic examination may show atrophy of the RPE at the fovea (Fig. 1B) and flecks in the macula that may become more widespread over time. Flecks correspond to deposits of lipofuscin in the RPE and in later stages can be seen as localized RPE atrophy with foveolar reflex 
blunted or absent. However, a third of the children with STGD do not have flecks on initial presentation. ${ }^{32}$

Visual acuity is not the only visual function affected in STGD. Deficits in color vision ${ }^{33}$ and central visual field ${ }^{34}$ progressively increase typically accompanying a decrease in visual acuity.

Fluorescein angiography (FA) demonstrates that the accumulation of lipofuscin in the RPE block the choroidal fluorescence, producing a dark or silent choroid. This sign is seen in approximately $75 \%$ of cases. ${ }^{28 ;} 35$

Both spectral-domain optical coherence tomography (SD-OCT) and fundus autofluorescence (AF) may show changes in the retina that are not identifiable by ophthalmoscopy and should be used in the initial evaluation.

The main OCT finding is a central loss of outer retinal layers (Fig. 2B); in the early-onset type, thickening of the external limiting membrane has been described. ${ }^{36}$ We use OCT in our evaluation of young children with possible STGD because it is non-invasive and image acquisition is quite quick.

AF is abnormal in STGD. Flecks are initially hyperfluorescent, reflecting the accumulation of lipofuscin in the RPE. With the progression of the RPE atrophy, the flecks become hypofluorecent. The pattern of the AF at the presentation of the disease is related to the enlargement of the retinal atrophy over time. ${ }^{37 ; 38} \mathrm{AF}$ has replaced the use of fluorescein angiography for evaluation of patients with suspected STGD.

Electrophysiological studies further characterized peripheral and central function in patients with STGD. Full field electroretinography (ffERG) results can be used to characterize peripheral function, while multi-focal electroretinography (mfERG) results can be used to characterize central function. $39 ; 40 ; 41$

Several interventions for STGD have been proposed, including light deprivation ${ }^{42}$, regulation of Vitamin $\mathrm{A}^{43 ; 44 ; 45 ; 46}$, gene-replacement therapy ${ }^{44}$, and human stem cell transplantation. ${ }^{44 ;} 47$ Information about current clinical treatment trials can be accessed at ClinicalTrials.gov.

\section{X-Linked Juvenile Retinoschisis}

$\mathrm{X}$-linked juvenile retinoschisis (XJR) is the leading inherited cause of macular degeneration in boys, with an estimated prevalence of 1 in 5,000 to 25,000 and accounts for approximately $5 \%$ of all childhood-onset, inherited retinal dystrophies. ${ }^{48}$

$\mathrm{XJR}$ is caused by mutation in the $R S 1$ gene, which is located on the short arm of the Xchromosome. $R S 1$ encodes retinoschisin, an extracellular binding protein which is secreted by retinal cells and characterized as a disulphide-linked octamer. ${ }^{49}$ Although all major classes of adult retinal neurons (with the possible exception of horizontal cells) express retinoschisin, $R S 1$ mRNA is expressed most abundantly in photoreceptor inner segments and in bipolar cells ${ }^{50}$, and serves as an adhesion molecule to maintain the structural and 
functional integrity of the retina, including the first synapse, that is, the synapse between photoreceptors and bipolar cells. This is a clue that the first synapse is likely critical to XJR pathology. ${ }^{51}$

There are three ways by which $R S 1$ mutations affect the function of retinoschisin. ${ }^{52}$ First, they alter the three-dimensional structure of the protein. Second, they impair the protein's ability to connect cells together (cell adhesion). And third, they cause the protein to be misplaced (i.e., trapped) within the retinal cells.

XJR affects young boys causing worsening vision over time, typically between the first and the second decade. It is usually bilateral; the ophthalmoscopic features may be asymmetric. The disease is clinically characterized by the formation of cavities within the retina, visible by ophthalmoscopy. The main clinical features are tiny splits within the retinal layers and, in the macula, a spoke-like pattern of cystic spaces between the outer plexiform and nuclear layers (Fig. 1C) ${ }^{53}$ Peripheral cystic spaces are associated with the formation of vitreous veils. These retinal changes put the boy at risk for impaired peripheral vision, vitreous hemorrhage, retinal holes, retinal detachment, progressively worsening vision, and even blindness. $^{54}$

The affected boys may present with moderately high hyperopia. The decrease of visual acuity may also be associated with a defect in color vision function with or without predominant (red-green) axis. ${ }^{55}$

OCT allows visualization of the macular and extra-macular regions to evaluate the presence of cystic spaces within the retinal layers (Fig. 2C). Some studies have shown that the outer plexiform layer (OPL) and inner nuclear layer (INL) are most affected. ${ }^{56 ; 57 ; 58 ; 59}$ Macular thickness (measured by OCT) may be used to monitor changes in the cavities. Retinal thickness is often asymmetric between the eyes, and not necessarily related to the visual acuity. ${ }^{60} \mathrm{OCT}$ is also useful to detect vitreo-retinal traction. ${ }^{61 ; 62}$

In addition to the formation of cavities within the retinal layers, which is the clinical hallmark of XJR, diminished transmission of the visual signal across the first synapse, between the photoreceptor and bipolar cell, is recognized as an important element of XJR pathology. ${ }^{63}$ This diminished transmission presents, electroretinographically, as a waveform with relatively greater attenuation of post-receptor responses ( $b$-wave) than of photoreceptor responses (a-wave). ${ }^{64}$ The cornea-positive $b$-wave is reduced disproportionately to the cornea-negative $a$-wave, resulting in a "negative ERG" in the early stage of XJR.

The biochemical mechanism of retinoschisin (RS) is not completely known. Treatment options continue to be evaluated, including both gene replacement and carbonic anhydrase inhibitors (CAIs). To date, all data pertaining to the efficacy of gene replacement in XJR has come from studies in the $R S 1$ "knockout" mouse ${ }^{65 ; 66 ; 67 ; 68}$, but retroviral gene-replacement therapies in humans are currently in Phase I/II clinical trials (see ClinicalTrials.gov). A CAI trial is also ongoing (see ClinicalTrials.gov). CAIs may be helpful in decreasing the cavities and retinal thickness. ${ }^{69}$ XJR eyes respond to CAIs with reduction in the volume of the cavities but show little improvement in acuity; it is unlikely that CAIs would provide direct treatment of the fundamental disease process. It is known that CAIs are effective therapies 
for cation channelopathies, such as primary hypo- and hyperkalemic periodic paralysis (PPP). ${ }^{70}$

\section{Best Vitelliform Macular Dystrophy}

Best vitelliform macular dystrophy (BVMD) is an early onset maculopathy with a characteristic deposit of a yellowish material, like egg yolk, in the macula. ${ }^{71}$

BVMD is caused by mutation in the BEST1 gene located on chromosome 11q13. ${ }^{72}$ This gene is also known as $V M D 2$ gene and encodes a protein, bestrophin- $1^{73}$, located in the basolateral membrane of the retinal pigment epithelial (RPE) cells. This protein is a calcium sensitive chloride channel. The effect of the mutation on this protein is not completely understood, but it is associated with accumulation of lipofuscin in the RPE.

BVMD is inherited in an autosomal dominant mode with incomplete penetrance. The mutations produce variable phenotypes, including an adult-onset vitelliform dystrophy. ${ }^{74}$

BVDM is usually a bilateral condition, but some cases with unilateral disease have been reported. ${ }^{75}$ The presentation is highly variable, but typically presents during the first or second decade, with worsening of visual acuity. BVDM can be completely asymptomatic and discovered as an incidental finding on examination of the eyes. A slow decline in visual acuity may occur over the years. ${ }^{76}$

Ophthalmoscopic findings vary as the disease progresses. ${ }^{77}$ There are three main stages that characterize the disease: the vitelliform stage, the pseudohypopyon stage, and the vitelliruptive stage. In the vitelliform stage, the cyst is a dome-shaped deposit of vitelliform material under the macula. In the pseudohypopyon stage, the cyst is both vitelliform material and clear fluid. In the vitelliruptive stage, the cyst is both vitelliform material and clear fluid but in a mottled and disorganized distribution (Fig. 1D). In later stages chorioretinal atrophy may be present. Some patients develop choroidal neovascularization under the lesions.

OCT shows both hypereflective and hyporeflective areas in the RPE and the ellipsoid zone (EZ). Hypereflective areas correspond with lipofuscin deposits seen by ophthalmoscopy. Hyporeflective areas are "optically empty" spaces that are located between the RPE and the EZ (Fig. 2D). In later stages, loss of the EZ and thinning of all the retinal layers may be seen. ${ }^{78 ;} 79$

A range of autofluorescense (AF) patterns is seen, including normal, hyperfluorescence, and hypofluorescence. Lipofuscin deposits correspond with areas of high $\mathrm{AF}^{78}$ The distribution of AF may be patchy, multifocal, or spoke-like. ${ }^{80}$

A classical finding in patients with BVMD is abnormal electrooculogram (EOG), characterized by an absent or significantly decreased light rise (Arden ratio less than 1.5). ${ }^{81}$ Today, a combination of clinical findings, OCT results, and genetic testing secures the diagnosis.

BVMD typically progresses with a slow decrease in the visual acuity. If an abrupt decrease in visual acuity occurs, development of a neovascular choroidal membrane should be 
suspected. The use of anti-vascular endothelial growth factor agents have been used in the treatment of this complication. ${ }^{82}$ Stem cell transplantation is also under investigation. ${ }^{71}$ (See ClinicalTrials.gov.)

\section{Conclusion}

We have reviewed three common juvenile macular degenerations: Stargardt disease, Xlinked retinoschisis, and Best vitelliform macular dystrophy. Each condition typically presents during childhood, when vision is still developing. The juvenile macular degenerations are sufficiently common that they should be considered in the differential diagnosis of visual loss in childhood.

\section{Acknowledgments}

Supported in part by Knights Templar Eye Foundation, Inc.; Massachusetts Lions Eye Research Fund; NIH/NEI 2R44EY018509.

\section{References}

1. Hendrickson AE, Yuodelis C. The morphological development of the human fovea. Ophthalmology. 1984; 91:603-12. [PubMed: 6462623]

2. Lee H, Purohit R, Patel A, Papageorgiou E, Sheth V, Maconachie G, et al. In Vivo Foveal Development Using Optical Coherence Tomography. Invest Ophthalmol Vis Sci. 2015; 56:4537-45. [PubMed: 26200492]

3. Yuodelis C, Hendrickson A. A qualitative and quantitative analysis of the human fovea during development. Vision Res. 1986; 26:847-55. [PubMed: 3750868]

4. Hendrickson A, Drucker D. The development of parafoveal and mid-peripheral human retina. Behav Brain Res. 1992; 49:21-31. [PubMed: 1388798]

5. Hendrickson A, Possin D, Vajzovic L, Toth CA. Histologic development of the human fovea from midgestation to maturity. Am J Ophthalmol. 2012; 154:767-78. e2. [PubMed: 22935600]

6. Vajzovic L, Hendrickson AE, O'Connell RV, Clark LA, Tran-Viet D, Possin D, et al. Maturation of the human fovea: correlation of spectral-domain optical coherence tomography findings with histology. Am J Ophthalmol. 2012; 154:779-89. e2. [PubMed: 22898189]

7. Cox, GF., Fulton, AB. Albinism. In: Levin, LA., Albert, DM., editors. Ocular Disease: Mechanism and Management. Saunders Elsevier; 2010. p. 461-71.

8. Thomas MG, Kumar A, Mohammad S, Proudlock FA, Engle EC, Andrews C, et al. Structural grading of foveal hypoplasia using spectral-domain optical coherence tomography a predictor of visual acuity? Ophthalmology. 2011; 118:1653-60. [PubMed: 21529956]

9. Tsina EK, Marsden DL, Hansen RM, Fulton AB. Maculopathy and retinal degeneration in cobalamin C methylmalonic aciduria and homocystinuria. Arch Ophthalmol. 2005; 123:1143-6. [PubMed: 16087854]

10. Dharmaraj S, Leroy BP, Sohocki MM, Koenekoop RK, Perrault I, Anwar K, et al. The phenotype of Leber congenital amaurosis in patients with AIPL1 mutations. Arch Ophthalmol. 2004; 122:1029-37. [PubMed: 15249368]

11. Kousal B, Dudakova L, Gaillyova R, Hejtmankova M, Diblik P, Michaelides M, et al. Phenotypic features of CRB1-associated early-onset severe retinal dystrophy and the different molecular approaches to identifying the disease-causing variants. Graefes Arch Clin Exp Ophthalmol. 2016; 254:1833-9. [PubMed: 27113771]

12. Perrault I, Hanein S, Zanlonghi X, Serre V, Nicouleau M, Defoort-Delhemmes S, et al. Mutations in NMNAT1 cause Leber congenital amaurosis with early-onset severe macular and optic atrophy. Nat Genet. 2012; 44:975-7. [PubMed: 22842229] 
13. Rosenberg T, Roos B, Johnsen T, Bech N, Scheetz TE, Larsen M, et al. Clinical and genetic characterization of a Danish family with North Carolina macular dystrophy. Mol Vis. 2010; 16:2659-68. [PubMed: 21179233]

14. Jack LS, Benson C, Sadiq MA, Rizzo WB, Margalit E. Segmentation of Retinal Layers in SjogrenLarsson Syndrome. Ophthalmology. 2015; 122:1730-2. [PubMed: 25784589]

15. Makino S, Ohkubo Y, Tampo H. Optical coherence tomography and fundus autofluorescence imaging study of chorioretinal atrophy involving the macula in Alagille syndrome. Clin Ophthalmol. 2012; 6:1445-8. [PubMed: 23055661]

16. Preising MN, Abura M, Jager M, Wassill KH, Lorenz B. Ocular morphology and function in juvenile neuronal ceroid lipofuscinosis (CLN3) in the first decade of life. Ophthalmic Genet. 2016:1-8. [PubMed: 24621175]

17. Krill AE, Deutman AF. The various categories of juvenile macular degeneration. Trans Am Ophthalmol Soc. 1972; 70:220-45. [PubMed: 4541358]

18. North V, Gelman R, Tsang SH. Juvenile-onset macular degeneration and allied disorders. Dev Ophthalmol. 2014; 53:44-52. [PubMed: 24732760]

19. Blacharski, P., editor. Fundus flavimaculatus. New York: Raven Press; 1988.

20. Allikmets R, Singh N, Sun H, Shroyer NF, Hutchinson A, Chidambaram A, et al. A photoreceptor cell-specific ATP-binding transporter gene (ABCR) is mutated in recessive Stargardt macular dystrophy. Nat Genet. 1997; 15:236-46. [PubMed: 9054934]

21. Cideciyan AV, Aleman TS, Swider M, Schwartz SB, Steinberg JD, Brucker AJ, et al. Mutations in ABCA4 result in accumulation of lipofuscin before slowing of the retinoid cycle: a reappraisal of the human disease sequence. Hum Mol Genet. 2004; 13:525-34. [PubMed: 14709597]

22. Song H, Rossi EA, Latchney L, Bessette A, Stone E, Hunter JJ, et al. Cone and rod loss in Stargardt disease revealed by adaptive optics scanning light ophthalmoscopy. JAMA Ophthalmol. 2015; 133:1198-203. [PubMed: 26247787]

23. Allikmets R, Wasserman WW, Hutchinson A, Smallwood P, Nathans J, Rogan PK, et al. Organization of the ABCR gene: analysis of promoter and splice junction sequences. Gene. 1998; 215:111-22. [PubMed: 9666097]

24. Zernant J, Xie YA, Ayuso C, Riveiro-Alvarez R, Lopez-Martinez MA, Simonelli F, et al. Analysis of the ABCA4 genomic locus in Stargardt disease. Hum Mol Genet. 2014; 23:6797-806. [PubMed: 25082829]

25. Michaelides M, Gaillard MC, Escher P, Tiab L, Bedell M, Borruat FX, et al. The PROM1 mutation p.R373C causes an autosomal dominant bull's eye maculopathy associated with rod, rod-cone, and macular dystrophy. Invest Ophthalmol Vis Sci. 2010; 51:4771-80. [PubMed: 20393116]

26. Karan G, Lillo C, Yang Z, Cameron DJ, Locke KG, Zhao Y, et al. Lipofuscin accumulation, abnormal electrophysiology, and photoreceptor degeneration in mutant ELOVL4 transgenic mice: a model for macular degeneration. Proc Natl Acad Sci U S A. 2005; 102:4164-9. [PubMed: 15749821]

27. Fujinami K, Zernant J, Chana RK, Wright GA, Tsunoda K, Ozawa Y, et al. Clinical and molecular characteristics of childhood-onset Stargardt disease. Ophthalmology. 2015; 122:326-34. [PubMed: 25312043]

28. Lambertus S, van Huet RA, Bax NM, Hoefsloot LH, Cremers FP, Boon CJ, et al. Early-onset stargardt disease: phenotypic and genotypic characteristics. Ophthalmology. 2015; 122:335-44. [PubMed: 25444351]

29. Fujinami K, Sergouniotis PI, Davidson AE, Wright G, Chana RK, Tsunoda K, et al. Clinical and molecular analysis of Stargardt disease with preserved foveal structure and function. Am J Ophthalmol. 2013; 156:487-501. e1. [PubMed: 23953153]

30. Rotenstreich Y, Fishman GA, Anderson RJ. Visual acuity loss and clinical observations in a large series of patients with Stargardt disease. Ophthalmology. 2003; 110:1151-8. [PubMed: 12799240]

31. van Huet RA, Bax NM, Westeneng-Van Haaften SC, Muhamad M, Zonneveld-Vrieling MN, Hoefsloot LH, et al. Foveal sparing in Stargardt disease. Invest Ophthalmol Vis Sci. 2014; 55:7467-78. [PubMed: 25324290]

32. Cukras CA, Wong WT, Caruso R, Cunningham D, Zein W, Sieving P. Fundus autofluorescence patterns in stargardt disease over time-reply. Arch Ophthalmol. 2012; 130:1354-5. 
33. Vandenbroucke T, Buyl R, De Zaeytijd J, Bauwens M, Uvijls A, De Baere E, et al. Colour Vision in Stargardt Disease. Ophthalmic Res. 2015; 54:181-94. [PubMed: 26492201]

34. Bernstein A, Sunness JS, Applegate CA, Tegins EO. Mapping the Dense Scotoma and Its Enlargement in Stargardt Disease. Retina. 2016; 36:1741-50. [PubMed: 26909568]

35. Fishman GA, Farber M, Patel BS, Derlacki DJ. Visual acuity loss in patients with Stargardt's macular dystrophy. Ophthalmology. 1987; 94:809-14. [PubMed: 3658351]

36. Lee W, Noupuu K, Oll M, Duncker T, Burke T, Zernant J, et al. The external limiting membrane in early-onset Stargardt disease. Invest Ophthalmol Vis Sci. 2014; 55:6139-49. [PubMed: 25139735]

37. Cideciyan AV, Swider M, Schwartz SB, Stone EM, Jacobson SG. Predicting Progression of ABCA4-Associated Retinal Degenerations Based on Longitudinal Measurements of the Leading Disease Front. Invest Ophthalmol Vis Sci. 2015; 56:5946-55. [PubMed: 26377081]

38. Fujinami K, Lois N, Mukherjee R, McBain VA, Tsunoda K, Tsubota K, et al. A longitudinal study of Stargardt disease: quantitative assessment of fundus autofluorescence, progression, and genotype correlations. Invest Ophthalmol Vis Sci. 2013; 54:8181-90. [PubMed: 24265018]

39. Fujinami K, Lois N, Davidson AE, Mackay DS, Hogg CR, Stone EM, et al. A longitudinal study of stargardt disease: clinical and electrophysiologic assessment, progression, and genotype correlations. Am J Ophthalmol. 2013; 155:1075-88. e13. [PubMed: 23499370]

40. Lois N, Holder GE, Bunce C, Fitzke FW, Bird AC. Phenotypic subtypes of Stargardt macular dystrophy-fundus flavimaculatus. Arch Ophthalmol. 2001; 119:359-69. [PubMed: 11231769]

41. Zahid S, Jayasundera T, Rhoades W, Branham K, Khan N, Niziol LM, et al. Clinical phenotypes and prognostic full-field electroretinographic findings in Stargardt disease. Am J Ophthalmol. 2013; 155:465-73. e3. [PubMed: 23219216]

42. Teussink MM, Lee MD, Smith RT, van Huet RA, Klaver CC, Klevering BJ, et al. The effect of light deprivation in patients with Stargardt disease. Am J Ophthalmol. 2015; 159:964-72. e2. [PubMed: 25681002]

43. Charbel Issa P, Barnard AR, Herrmann P, Washington I, MacLaren RE. Rescue of the Stargardt phenotype in Abca4 knockout mice through inhibition of vitamin A dimerization. Proc Natl Acad Sci U S A. 2015; 112:8415-20. [PubMed: 26106163]

44. Lu LJ, Liu J, Adelman RA. Novel therapeutics for Stargardt disease. Graefes Arch Clin Exp Ophthalmol. 2017

45. Radu RA, Han Y, Bui TV, Nusinowitz S, Bok D, Lichter J, et al. Reductions in serum vitamin A arrest accumulation of toxic retinal fluorophores: a potential therapy for treatment of lipofuscinbased retinal diseases. Invest Ophthalmol Vis Sci. 2005; 46:4393-401. [PubMed: 16303925]

46. Radu RA, Mata NL, Nusinowitz S, Liu X, Sieving PA, Travis GH. Treatment with isotretinoin inhibits lipofuscin accumulation in a mouse model of recessive Stargardt's macular degeneration. Proc Natl Acad Sci U S A. 2003; 100:4742-7. [PubMed: 12671074]

47. Schwartz SD, Regillo CD, Lam BL, Eliott D, Rosenfeld PJ, Gregori NZ, et al. Human embryonic stem cell-derived retinal pigment epithelium in patients with age-related macular degeneration and Stargardt's macular dystrophy: follow-up of two open-label phase 1/2 studies. Lancet. 2015; 385:509-16. [PubMed: 25458728]

48. George ND, Yates JR, Moore AT. X linked retinoschisis. Br J Ophthalmol. 1995; 79:697-702. [PubMed: 7662639]

49. Wu WW, Wong JP, Kast J, Molday RS. RS1, a discoidin domain-containing retinal cell adhesion protein associated with X-linked retinoschisis, exists as a novel disulfide-linked octamer. J Biol Chem. 2005; 280:10721-30. [PubMed: 15644328]

50. Molday LL, Hicks D, Sauer CG, Weber BH, Molday RS. Expression of X-linked retinoschisis protein RS1 in photoreceptor and bipolar cells. Invest Ophthalmol Vis Sci. 2001; 42:816-25. [PubMed: 11222545]

51. Ou J, Vijayasarathy C, Ziccardi L, Chen S, Zeng Y, Marangoni D, et al. Synaptic pathology and therapeutic repair in adult retinoschisis mouse by AAV-RS1 transfer. J Clin Invest. 2015; 125:2891-903. [PubMed: 26098217]

52. Sergeev YV, Vitale S, Sieving PA, Vincent A, Robson AG, Moore AT, et al. Molecular modeling indicates distinct classes of missense variants with mild and severe XLRS phenotypes. Hum Mol Genet. 2013; 22:4756-67. [PubMed: 23847049] 
53. Gerth C, Zawadzki RJ, Werner JS, Heon E. Retinal morphological changes of patients with Xlinked retinoschisis evaluated by Fourier-domain optical coherence tomography. Arch Ophthalmol. 2008; 126:807-11. [PubMed: 18541843]

54. Eksandh LC, Ponjavic V, Ayyagari R, Bingham EL, Hiriyanna KT, Andreasson S, et al. Phenotypic expression of juvenile X-linked retinoschisis in Swedish families with different mutations in the XLRS1 gene. Arch Ophthalmol. 2000; 118:1098-104. [PubMed: 10922205]

55. Kellner U, Brummer S, Foerster MH, Wessing A. X-linked congenital retinoschisis. Graefes Arch Clin Exp Ophthalmol. 1990; 228:432-7. [PubMed: 2227486]

56. Akeo K, Kameya S, Gocho K, Kubota D, Yamaki K, Takahashi H. Detailed Morphological Changes of Foveoschisis in Patient with X-Linked Retinoschisis Detected by SD-OCT and Adaptive Optics Fundus Camera. Case Rep Ophthalmol Med. 2015; 2015:432782. [PubMed: 26356828]

57. Hu QR, Huang LZ, Chen XL, Xia HK, Li TQ, Li XX. X-Linked Retinoschisis in Juveniles: Follow-Up by Optical Coherence Tomography. Biomed Res Int. 2017; 2017:1704623. [PubMed: 28286756]

58. Wang NK, Liu L, Chen HM, Tsai S, Chang TC, Tsai TH, et al. Clinical presentations of X-linked retinoschisis in Taiwanese patients confirmed with genetic sequencing. Mol Vis. 2015; 21:487501. [PubMed: 25999676]

59. Yang HS, Lee JB, Yoon YH, Lee JY. Correlation between spectral-domain OCT findings and visual acuity in X-linked retinoschisis. Invest Ophthalmol Vis Sci. 2014; 55:3029-36. [PubMed: 24713485]

60. Andreoli MT, Lim JI. Optical coherence tomography retinal thickness and volume measurements in X-linked retinoschisis. Am J Ophthalmol. 2014; 158:567-73. e2. [PubMed: 24879947]

61. George ND, Yates JR, Moore AT. Clinical features in affected males with X-linked retinoschisis. Arch Ophthalmol. 1996; 114:274-80. [PubMed: 8600886]

62. Jeffrey BG, Cukras CA, Vitale S, Turriff A, Bowles K, Sieving PA. Test-Retest Intervisit Variability of Functional and Structural Parameters in X-Linked Retinoschisis. Transl Vis Sci Technol. 2014; 3:5.

63. Weber BH, Schrewe H, Molday LL, Gehrig A, White KL, Seeliger MW, et al. Inactivation of the murine X-linked juvenile retinoschisis gene, Rs1h, suggests a role of retinoschisin in retinal cell layer organization and synaptic structure. Proc Natl Acad Sci U S A. 2002; 99:6222-7. [PubMed: 11983912]

64. Khan NW, Jamison JA, Kemp JA, Sieving PA. Analysis of photoreceptor function and inner retinal activity in juvenile X-linked retinoschisis. Vision Res. 2001; 41:3931-42. [PubMed: 11738458]

65. Byrne LC, Ozturk BE, Lee T, Fortuny C, Visel M, Dalkara D, et al. Retinoschisin gene therapy in photoreceptors, Muller glia or all retinal cells in the Rs1h-/- mouse. Gene Ther. 2014; 21:585-92. [PubMed: 24694538]

66. Janssen A, Min SH, Molday LL, Tanimoto N, Seeliger MW, Hauswirth WW, et al. Effect of latestage therapy on disease progression in AAV-mediated rescue of photoreceptor cells in the retinoschisin-deficient mouse. Mol Ther. 2008; 16:1010-7. [PubMed: 18388913]

67. Kjellstrom S, Bush RA, Zeng Y, Takada Y, Sieving PA. Retinoschisin gene therapy and natural history in the Rs1h-KO mouse: long-term rescue from retinal degeneration. Invest Ophthalmol Vis Sci. 2007; 48:3837-45. [PubMed: 17652759]

68. Takada Y, Vijayasarathy C, Zeng Y, Kjellstrom S, Bush RA, Sieving PA. Synaptic pathology in retinoschisis knockout (Rs1-/y) mouse retina and modification by rAAV-Rs1 gene delivery. Invest Ophthalmol Vis Sci. 2008; 49:3677-86. [PubMed: 18660429]

69. Apushkin MA, Fishman GA. Use of dorzolamide for patients with X-linked retinoschisis. Retina. 2006; 26:741-5. [PubMed: 16963845]

70. Tawil R, McDermott MP, Brown R Jr, Shapiro BC, Ptacek LJ, McManis PG, et al. Randomized trials of dichlorphenamide in the periodic paralyses. Working Group on Periodic Paralysis. Ann Neurol. 2000; 47:46-53. [PubMed: 10632100]

71. Johnson AA, Guziewicz KE, Lee CJ, Kalathur RC, Pulido JS, Marmorstein LY, et al. Bestrophin 1 and retinal disease. Prog Retin Eye Res. 2017 
72. Petrukhin K, Koisti MJ, Bakall B, Li W, Xie G, Marknell T, et al. Identification of the gene responsible for Best macular dystrophy. Nat Genet. 1998; 19:241-7. [PubMed: 9662395]

73. Marmorstein AD, Marmorstein LY, Rayborn M, Wang X, Hollyfield JG, Petrukhin K. Bestrophin, the product of the Best vitelliform macular dystrophy gene (VMD2), localizes to the basolateral plasma membrane of the retinal pigment epithelium. Proc Natl Acad Sci U S A. 2000; 97:1275863. [PubMed: 11050159]

74. Boon CJ, Klevering BJ, Leroy BP, Hoyng CB, Keunen JE, den Hollander AI. The spectrum of ocular phenotypes caused by mutations in the BEST1 gene. Prog Retin Eye Res. 2009; 28:187205. [PubMed: 19375515]

75. Arora R, Khan K, Kasilian ML, Strauss RW, Holder GE, Robson AG, et al. Unilateral BEST1Associated Retinopathy. Am J Ophthalmol. 2016; 169:24-32. [PubMed: 27287821]

76. Booij JC, Boon CJ, van Schooneveld MJ, ten Brink JB, Bakker A, de Jong PT, et al. Course of visual decline in relation to the Best1 genotype in vitelliform macular dystrophy. Ophthalmology. 2010; 117:1415-22. [PubMed: 20381869]

77. Agarwal, A. Gass' Atlas of Macular Diseases. 5. Elsevier Health Sciences; 2011.

78. Boon CJ, Theelen T, Hoefsloot EH, van Schooneveld MJ, Keunen JE, Cremers FP, et al. Clinical and molecular genetic analysis of best vitelliform macular dystrophy. Retina. 2009; 29:835-47. [PubMed: 19357557]

79. Querques G, Regenbogen M, Quijano C, Delphin N, Soubrane G, Souied EH. High-definition optical coherence tomography features in vitelliform macular dystrophy. Am J Ophthalmol. 2008; 146:501-7. [PubMed: 18619572]

80. Parodi MB, Iacono P, Campa C, Del Turco C, Bandello F. Fundus autofluorescence patterns in Best vitelliform macular dystrophy. Am J Ophthalmol. 2014; 158:1086-92. [PubMed: 25068640]

81. Testa F, Rossi S, Passerini I, Sodi A, Di Iorio V, Interlandi E, et al. A normal electro-oculography in a family affected by best disease with a novel spontaneous mutation of the BEST1 gene. $\mathrm{Br} \mathrm{J}$ Ophthalmol. 2008; 92:1467-70. [PubMed: 18703557]

82. Ruiz-Moreno O, Calvo P, Ferrandez B, Torron C. Long-term outcomes of intravitreal ranibizumab for choroidal neovascularization secondary to Best's disease, 3-year follow-up. Acta Ophthalmol. 2012; 90:e574-5. [PubMed: 22339886] 


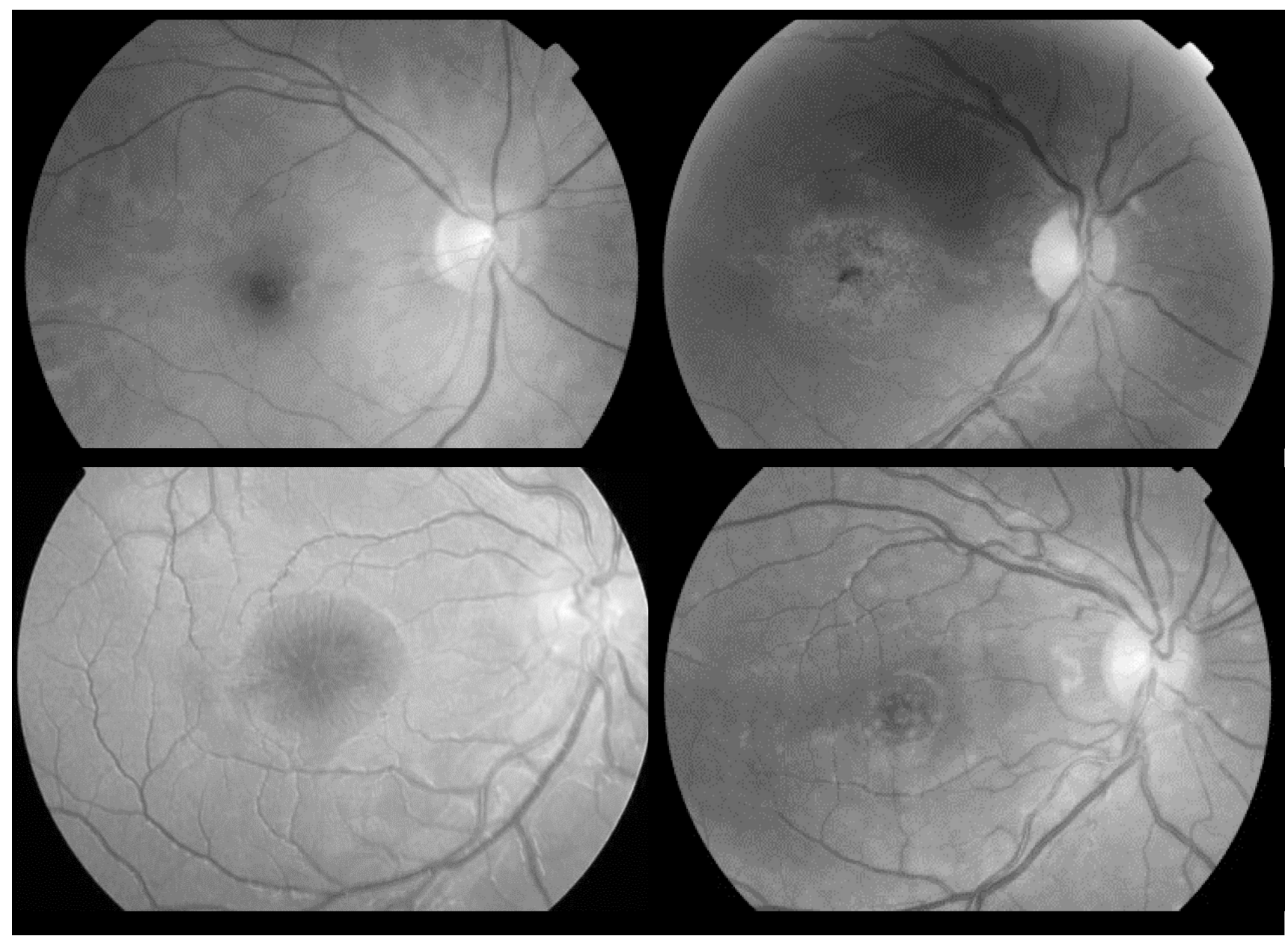

Figure 1.

Fundus photos showing a normal macula and examples of the typical macular findings in common juvenile macular degenerations. A) Normal macula. B) STGD showing atrophic macular region. C) XJR showing the classical "spoke-like" pattern in the macula. D) BVMD showing vitelliform material and clear fluid in a mottled distribution in the macula. STGD: Stargardt's disease; XJR: X-linked retinoschisis; BVMD: Best vitelliform macular dystrophy 

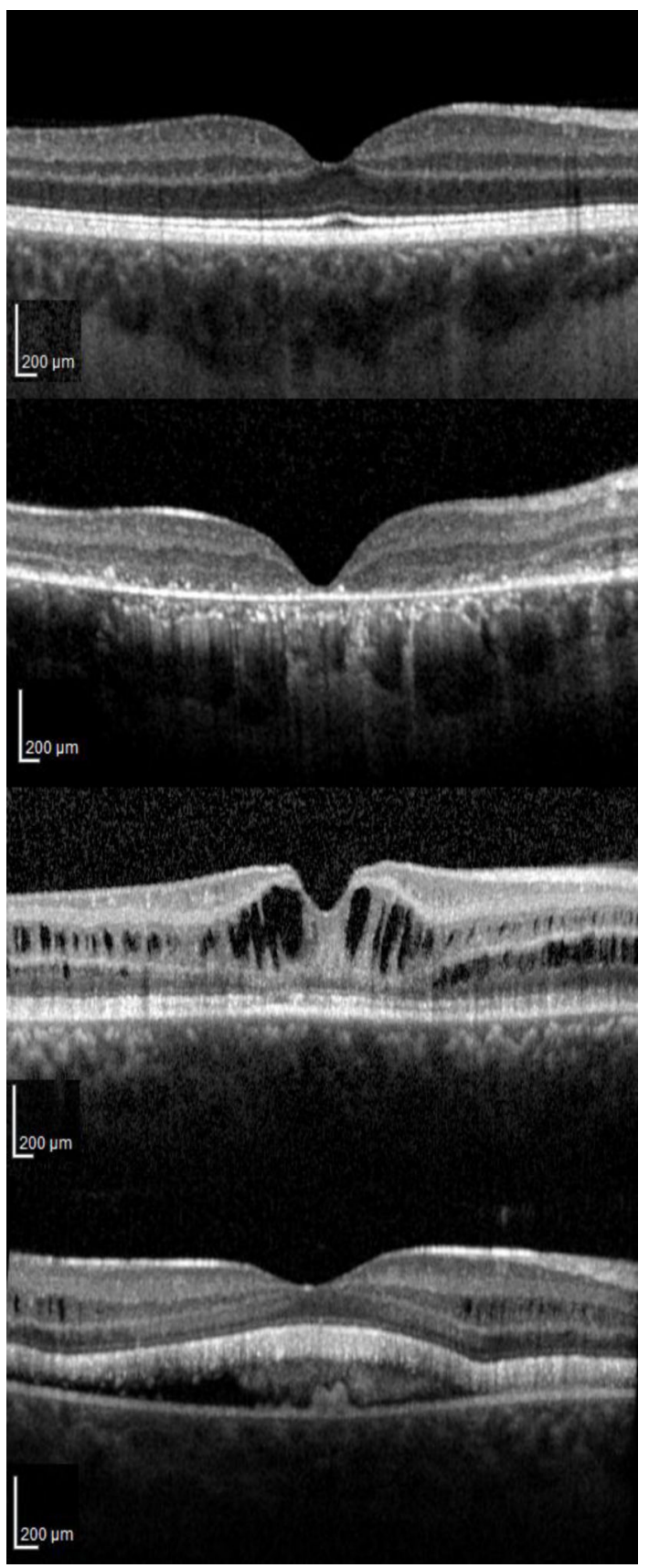

Figure 2.

Spectral domain ocular coherence tomography (SD-OCT) scans showing a normal macula and examples of the typical macular findings in common juvenile macular degenerations. A) Normal macula showing all of the retinal layers. B) STGD showing absence of the outer retinal layers, with a significant thinning at the level of the fovea. C) XJR showing the presence of cystic spaces within the retinal layers. D) BVMD showing a heterogeneous material with hypereflective areas and some optical empty areas under the fovea. STGD: 
Stargardt's disease; XJR: X-linked retinoschisis; BVMD: Best vitelliform macular dystrophy 